saline suspensions of washed red blood cells. This lysis is observed consistently only if the tissues are themselves first thoroughly washed or rinsed in saline. On the other hand, tissue slices have little or no lytic effect on suspensions of unwashed red cells.

Inhibition of this lysis is produced by : (a) The addition of the animal's serum to the mixture of tissue plus red cell suspension. This inhibitory effect of serum is not confined to the animal's own species, but can be produced by the exhibition of sera of other species. The inhibitory effect of heterologous sera is, however, observable only in a definite zone of dilution. This is particularly noticeable in the case of human serum, which in low dilutions has been found to lyse guinea pig red. cells even in the absence of washed tissue. (b) The addition of sodium cyanide in a dilution of as little as 1 in $20,000,000$ and of mercuric chloride in a dilution of 1 in 32,000 . (c) Heating the tissue to a temperature of $80^{\circ} \mathrm{C}$. or above for a period long enough to affect all the tissue used in the experiment.

Species used in these experiments have been man, monkeys (Cercopithecus, Erythrocebus, Colobus) and guinea pig. So far as our experiments have gone, the lytic agent appears to be species specific, while the serum inhibitor is not.

Consistent results have been obtained with guinea pig tissue, using washed guinea pig lung as the lytic agent and a 5 per cent physiological saline suspension of guinea pig red cells, washed three times in physiological saline, with or without the addition of 5 per cent glucose.

In the uninhibited red cell suspension - washed tissue system, lysis is completed in 18-24 hours.

The strictest aseptic technique must be employed throughout these experiments. It is essential that all glassware should be scrupulously clean by chemical standards.

It is difficult to conceive that the lytic agent demonstrated by the above experiments can be other than an enzyme, although as yet we have been unable to perform the crucial respiratory experiments. If our contention is correct, there exists in the animal body an enzyme capaible of destroying red cells. The activities of this agent are held in check by an inhibiting substance which is present in both the tissues and the blood serum. The degree of lysis occurring at any time in the animal body may thus depend upon the balance of inhibitor over lytic enzyme activity. Abnormal degrees of lysis such as those met in blackwater fever and other lytic anæmias may therefore be due either to interference with the activity of the inhibitor or to its actual destruction.

Brian Maegratth.

G. M. FIndLaY.

N. H. Martin.

West African Force. Dec. 21.

\section{A New Land Nemertean}

Is January 1938, Yngvar Hagen, zoologist of the Norwegian Scientific Expedition to Tristan da Cunha (1937-38), discovered a new nemertean species on Nightingale Island. The animal was found attached to the underside of boulder stones situated on a beach, though far above the high-water mark. The fauna of the area was quite a terrestrial one, as land snails, mites and spiders were also found there. The worm was later handed to me for a closer examination, and this investigation has now been finished. Publication of the paper must wait until after the War, but I should like nevertheless to place this interesting find on scientific record now.

The animal turned out to be a new species of terrestrial nemertean, belonging to the genus $\mathrm{Geo}$ nemertes Semp., which $\mathrm{I}$ have called Geonemertes nightingaleensis, n. sp. The length varied from 3 to $29 \mathrm{~mm}$. In colour it is olive-grey, with two broader black-brown dorsal stripes. Four eyes were found. The animal is characteristic in its lack of an accessory lateral nerve and a frontal organ, the cephalic gland, however, being well developed. The animal seems to be more closely related to $G$. agricola and $G$. chalicophora than to the other members of the genus.

August Brinkmann (jun.).

c/o Gothenburg Museum of Natural History, Gothenburg.

Jan. 11.

\section{Middle-Piece Beads in the Cavia Spermatozoon}

Ir is well known ${ }^{1}$ that the silver nitrate methods of Da Fano, Cajal and Aoyama for the Golgi apparatus impregnate densely a bead just around the neck of the guinea pig sperm (Fig. 1, NB). It has been assumed that this bead is identical with the middlepiece bead depicted by Retzius ${ }^{2}$ in so many kinds of mammalian spermatozoa.

We have recently been studying the spermatogenesis of the dog, and in trying to clear up some difficult points, we have reviewed the spermatogenesis of the cavy. We have been able to show that there are two beads on the spermatozoa from the epididymis, as shown in Fig. 1. The upper $(N B)$ is extremely argentophile, and we have easily followed it back to the early spermatocyte in both the dog and the cavy (Fig. 3), as a vesicle almost invariably lying against the sphere (Golgi apparatus). The lower $(M P B)$ is certainly the structure depicted by Retzius (Taf. XLV, Fig. 3, etc.) and so far we have

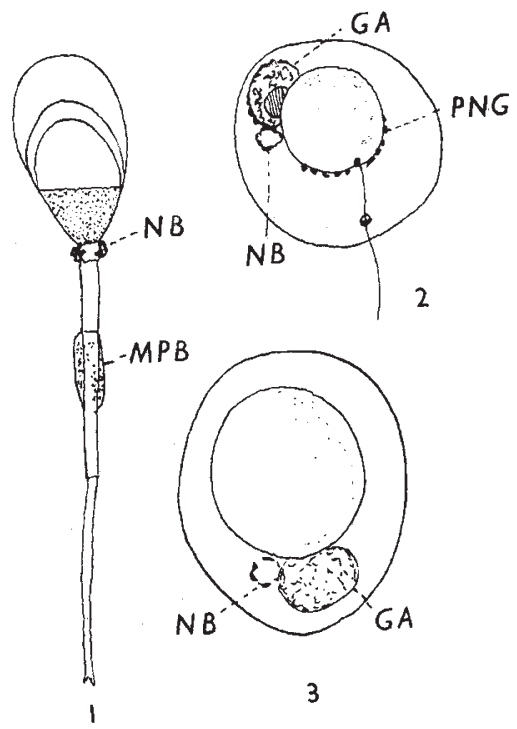

